\title{
Feral Horse Demography: A Preliminary
} Report

\author{
MICHAEL L. WOLFE, JR.
}

\begin{abstract}
The demographic characteristics of 18 feral horse (Equus caballus) populations in five states are discussed. As estimated primarily from the results of composition counts, foals comprised an average 19 percent (post-parturition) of the populations analyzed. Various procedures were employed in an attempt to estimate survival rates within the populations. Provisional estimates of first-year survival rates span the general range of 50-70 percent, while those for adults may approximate 80-85 percent. Annual rates of increase, predicted from simulation runs with the estimated population parameters, were considerably lower than those "observed" from aerial inventories in successive years. Possible explanations for these discrepancies and management implications are discussed.
\end{abstract}

Feral horses (Equus caballus) represent one of the most complicated problems of contemporary wildlife management. Under the protection afforded them by the provisions of the Wild Horse and Burro Act (PL 92-195), enacted in 1971 , populations of these animals have increased rapidly in recent years in many areas of the western United States. The acutal rates of increase remain the subject of considerable controversy. Aside from the stringent protective provisions of PL 92-195, the rational management of feral equid populations is hampered by a paucity of reliable information on the ecology (particularly demographic characteristics) of tree-ranging horses and burros (E. asinus) on the one hand, and on the other, the constraints imposed by the demands of special interest groups and the emotional issues involved.

The following report summarizes provisional information on the population ecology of free-ranging horses in several locations. It should be emphasized that the estimates of the demographic parameters given herein are tentative at best and that a primary objective of this paper is to point out the shortcomings of the existing data as well as areas requiring additional research. Perhaps this may serve as the impetus for the future collection of more reliable data.

\section{Data Sources}

This study grew out of a short-term (1976-77) investigation of feral horses on Dinosaur National Monument in northwestern Colorado. The field data, collected in the course of that investigation were supplemented by information obtained from the Bureau of Land Management records for feral horse populations from several locations. Some of the data from the California, Nevada, and Oregon populations that are analyzed herein have been reported previously (U.S. Dept. Interior 1976, Heady and Bartolome 1977).

The basic data derive from three primary sources: (1) aerial

\footnotetext{
The author is associate professor, Department of Wildlife Science, Utah State University, Logan, Utah 84322

Partial financial support for this study was provided by a contract (PX 120070496) from the National Park Service. The author gratefully acknowledges the assistance of F.D. Provenza in field work conducted in June 1977. Thanks are also due numerous Bureau of Land Management personnel, in particular M.N. Frei and W. Lawhorn, for their suggestions and help in obtaining data from various populations. J.A. Kadlec and L.L. Eberhardt reviewed the manuscript.

Manuscript received May 1, 1979.
}

inventories; (2) classification counts of sex and age composition; and (3) the age distributions of animals captured during reduction operations, or in one case, simply found dead. The ages of these animals (\#3) were estimated by criteria of tooth succession and wear (Emsminger 1951, Bone 1964). Since these data were collected by different personnel under a variety of conditions and undoubtedly with varying degrees of reliability, the results of the analyses there of should be interpreted with due caution.

In order to simplify the presentation of data, the various populations studied were assigned coded designations, which are given in the Appendix. Figure 1 shows approximate locations of the respective populations. The term "population" is used advisedly throughout the following report. In some cases the demographic entities constitute merely the horses within the boundaries of an arbitrarily defined administrative unit. In reality, these entities may comprise only a sub-population of a larger population or two or more discrete populations.

\section{Results and Discussion}

\section{Implied Rates of Increase}

Aerial trend counts constitute the source of demographic information most routinely collected from feral horse populations. Indices of the average annual rates of increase $(\lambda)$ for the populations studied here were derived from regressions of the count data from the respective populations as a function of time. These time series were fit to an exponential function of a form analogous to the standard model of

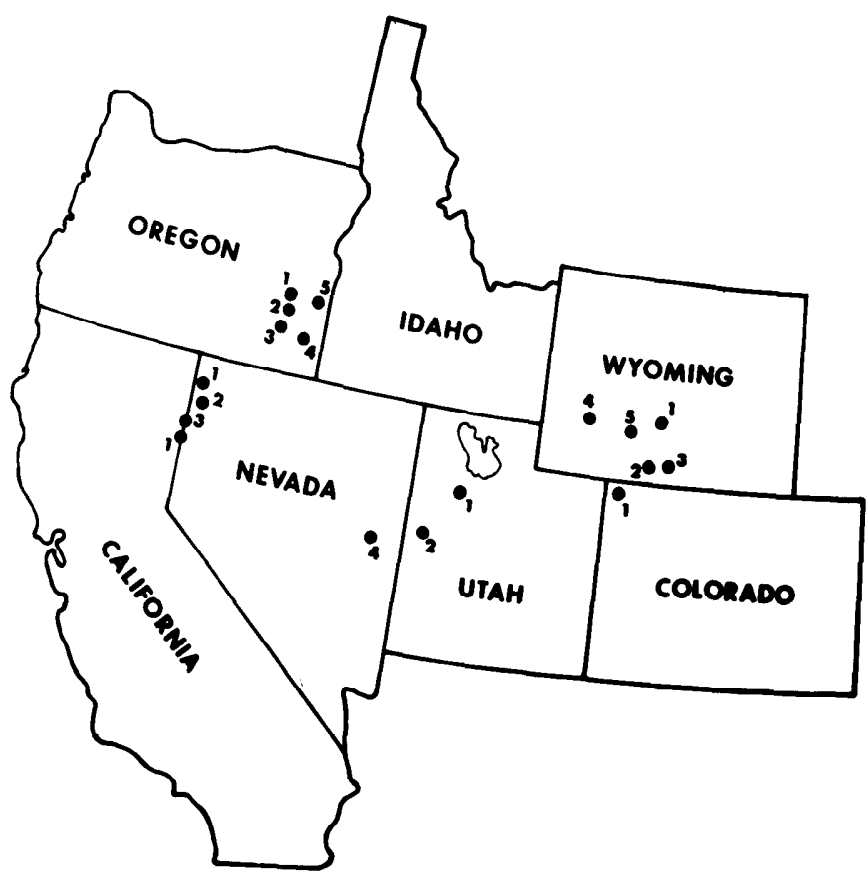

Fig. 1. Approximate locations of feral horse populations analyzed in this study. 
exponential population growth (vide: Caughley 1977).

$$
N_{\mathrm{t}}=N_{0} e^{r t}
$$

where: $N=$ population size

$\mathrm{e}=$ base of the natural logarithms

$r=$ exponential rate of population increase

$t=$ time interval (years)

Note that the finite rate of increase $(\lambda)$ is equivalent to $e^{r}$.

The use of an exponential growth model was predicted on the perhaps tenuous assumption that the populations analyzed were well below their respective carrying capacities and increasing in the absence of any obvious density dependent effects (i.e. in the exponential phase of a logistic growth curve).

The results of these regression analyses are given in Table 1. In some cases the count data for different years are not comparable, since some were obtained from fixed-winged aircraft while others were made with helicopters. No attempt was made to separate these data in the computation of the regression equations. Given the questionable reliability of regression measures developed from time series and the problems inherent in the population estimates from which they were computed, the implied rates of increase are suspect.

\section{Reproduction}

Productivity indices were estimated from the relative age composition (percent foals) in the respective populations, as determined in most cases from the results of aerial or ground-based classification surveys. These indices are summarized in Table 2. The table includes only the results of

Table 1. Implied growth rates for several feral horse popultions.

\begin{tabular}{|c|c|c|c|}
\hline Population & $\begin{array}{l}\text { Time span and } \\
\text { range of popula- } \\
\text { tion estimates }\end{array}$ & $\begin{array}{l}\text { Regression equations } \\
\text { and correlation } \\
\text { coefficient }\end{array}$ & $\begin{array}{c}\text { Rate of } \\
\text { increase }(\lambda)\end{array}$ \\
\hline Calif-1 & $\begin{array}{c}1973-1975 \\
(1,491-2,487)\end{array}$ & $\begin{array}{l}y=1173.60 \mathrm{e}^{0.26 t} \\
\mathrm{r}=0.99\end{array}$ & 1.30 \\
\hline Colo-1 & $\begin{array}{l}1972-1978 \\
(150-608)\end{array}$ & $\begin{array}{l}y=127.33 e^{0.22 t} \\
r=0.98^{*}\end{array}$ & 1.25 \\
\hline Neva-1 & $\begin{array}{l}1973-1975 \\
(127-148)\end{array}$ & $\begin{array}{l}y=117.62 e^{0.08 t} \\
r=1.00^{* *}\end{array}$ & 1.08 \\
\hline Neva-2 & $\begin{array}{l}1973-1975 \\
(177-236)\end{array}$ & $\begin{array}{l}y=153.94 e^{0.14 t} \\
r=1.00^{* *}\end{array}$ & 1.15 \\
\hline Neva-3 & $\begin{array}{l}1973-1975 \\
(179-287)\end{array}$ & $\begin{array}{l}y=141.64 e^{0.24 t} \\
r=1.00\end{array}$ & 1.27 \\
\hline Ore -4 & $\begin{array}{c}1972-1974 \\
(94-140)\end{array}$ & $\begin{array}{l}y=76.64 e^{0.20 t} \\
r=1.00^{* *}\end{array}$ & 1.22 \\
\hline Utah-2 & $\begin{array}{l}1972-1977 \\
(132-413)\end{array}$ & $\begin{array}{l}y=103.71 e^{0.25 t} \\
r=0.96^{* *}\end{array}$ & 1.28 \\
\hline Wyo-1 & $\begin{array}{l}1974-1976 \\
(151-238)\end{array}$ & $\begin{array}{l}y=121.20 e^{0.23 t} \\
r=0.97\end{array}$ & 1.26 \\
\hline Wyo-2 & $\begin{array}{c}1974-1976 \\
(647-1,002)\end{array}$ & $\begin{array}{l}y=535.74 e^{0.22 t} \\
r=0.97\end{array}$ & 1.25 \\
\hline Wyo-3 & $\begin{array}{l}1974-1976 \\
(517-667)\end{array}$ & $\begin{array}{l}y=464.73 e^{0.13 t} \\
r=0.96\end{array}$ & 1.14 \\
\hline Wyo-4 & $\begin{array}{l}1972-1976 \\
(213-538)\end{array}$ & $\begin{array}{l}y=153.73 e^{0.20 t} \\
r=0.83(N S)\end{array}$ & 1.22 \\
\hline Wyo-5 & $\begin{array}{c}1972-1976 \\
(535-1,132)\end{array}$ & $\begin{array}{l}y=439.30 e^{0.18 t} \\
r=0.99^{* *}\end{array}$ & 1.20 \\
\hline
\end{tabular}

*Significant at 0.05 level

** Significant at 0.01 level counts in which at least 100 animals were classified. The substantial procedural differences-both temporal and methodological-involved in the various surveys preclude any meaningful statistical analysis of the data or compari-

Table 2. Relative age composition (foals and yearlings) of several feral horse populations.

\begin{tabular}{|c|c|c|c|c|}
\hline Population & Survey date & $\begin{array}{l}\text { Sample } \\
\text { size }^{\mathrm{a}}\end{array}$ & $\begin{array}{l}\text { Percent } \\
\text { foals }\end{array}$ & $\begin{array}{l}\text { Percent } \\
\text { yearlings }\end{array}$ \\
\hline Calif-1 & $\begin{array}{l}\text { Feb. } 1973 \\
\text { Aug. } 1973 \\
\text { Aug. } 1974 \\
\text { Feb. } 1975 \\
\text { Aug. } 1975\end{array}$ & $\begin{array}{r}834 \\
1491 \\
2023 \\
1925 \\
2487\end{array}$ & $\begin{array}{r}7.7 \\
19.8 \\
20.2 \\
14.9 \\
18.0\end{array}$ & $\begin{array}{l}--- \\
--- \\
--- \\
--- \\
--\end{array}$ \\
\hline Colo-1 & $\begin{array}{l}\text { June } 1977 \\
\text { June-Nov. } 1977\end{array}$ & $\begin{array}{l}138^{b} \\
423^{c}\end{array}$ & $\begin{array}{l}21.0 \\
13.9\end{array}$ & $\begin{array}{l}7.2 \\
9.7\end{array}$ \\
\hline Neva-1 & $\begin{array}{l}\text { Feb. } 1973 \\
\text { Aug. } 1973 \\
\text { Aug. } 1974 \\
\text { Feb. } 1975 \\
\text { Aug. } 1975\end{array}$ & $\begin{array}{l}116 \\
127 \\
137 \\
147 \\
148\end{array}$ & $\begin{array}{l}14.7 \\
21.3 \\
22.6 \\
19.0 \\
20.3\end{array}$ & $\begin{array}{l}--- \\
--- \\
--- \\
-\ldots\end{array}$ \\
\hline Neva-2 & $\begin{array}{l}\text { Feb. } 1973 \\
\text { Aug. } 1973 \\
\text { Aug. } 1974 \\
\text { Feb. } 1975 \\
\text { Aug. } 1975\end{array}$ & $\begin{array}{l}136 \\
177 \\
207 \\
215 \\
236\end{array}$ & $\begin{array}{l}14.0 \\
19.8 \\
13.0 \\
17.7 \\
18.6\end{array}$ & $\begin{array}{l}-- \\
-\ldots \\
-\ldots \\
-\ldots \\
--\end{array}$ \\
\hline Neva-3 & $\begin{array}{l}\text { Feb. } 1973 \\
\text { Aug. } 1973 \\
\text { Aug. } 1974 \\
\text { Feb. } 1975 \\
\text { Aug. } 1975\end{array}$ & $\begin{array}{l}222 \\
179 \\
228 \\
223 \\
287\end{array}$ & $\begin{array}{l}13.1 \\
17.9 \\
18.0 \\
13.9 \\
19.5\end{array}$ & $\begin{array}{l}--- \\
--- \\
--- \\
--\end{array}$ \\
\hline Neva-4 & $\begin{array}{l}\text { Oct. } 1974 \\
\text { Mar. } 1975\end{array}$ & $\begin{array}{l}120^{\mathrm{b}} \\
118\end{array}$ & $\begin{array}{r}11.7 \\
5.1\end{array}$ & $-\square$ \\
\hline Ore-1 & Apr. 1975 & 208 & 13.0 & -- \\
\hline Ore-2 & Apr. 1975 & 147 & 12.9 & - - \\
\hline Ore-3 & Apr. 1975 & 1128 & 15.6 & -- \\
\hline Ore -4 & Apr. 1975 & 222 & 16.2 & - - \\
\hline Ore-5 & $\begin{array}{l}\text { Apr. } 1975 \\
\text { Dec. } 1975\end{array}$ & $\begin{array}{l}444 \\
255^{\mathrm{c}}\end{array}$ & $\begin{array}{l}14.6 \\
19.6\end{array}$ & $\overline{10.2}$ \\
\hline Utah-1 & $\begin{array}{l}\text { Jan. } 1975 \\
\text { Aug. } 1975 \\
\text { Jan. } 1976 \\
\text { June } 1976 \\
\text { Feb. } 1977\end{array}$ & $\begin{array}{l}173 \\
165 \\
134 \\
219 \\
124\end{array}$ & $\begin{array}{l}17.9 \\
12.1 \\
17.9 \\
18.7 \\
17.7\end{array}$ & $\begin{array}{l}7.9 \\
\overline{7.3} \\
-\end{array}$ \\
\hline Utah-2 & 1976 & $536^{\mathrm{b}}$ & 18.5 & -- \\
\hline Wyo-1 & $\begin{array}{l}\text { Summer } 1975 \\
\text { Mar. } 1976 \\
\text { May } 1976 \\
\text { Aug. } 1976\end{array}$ & $\begin{array}{l}233 \\
238 \\
224 \\
307\end{array}$ & $\begin{array}{l}20.6 \\
11.3 \\
17.4 \\
17.6\end{array}$ & $\frac{7.7}{-\square-}$ \\
\hline Wyo-2 & $\begin{array}{l}\text { Winter } 1975 \\
\text { Feb.-Mar. } 1976\end{array}$ & $\begin{array}{r}881 \\
1002\end{array}$ & $\begin{array}{r}9.1 \\
13.0\end{array}$ & - \\
\hline Wyo-3 & $\begin{array}{l}\text { Winter } 1974 \\
\text { Summer } 1974 \\
\text { Winter } 1975 \\
\text { Feb.-Mar. } 1976\end{array}$ & $\begin{array}{l}517 \\
536 \\
625 \\
667\end{array}$ & $\begin{array}{r}5.8 \\
15.7 \\
11.7 \\
14.8\end{array}$ & - \\
\hline
\end{tabular}

Unweighted mean percentage of foals in "post-parturition"(June-August) counts $=18.6$

Unweighted mean percentage of folas in "pre-parturition" (JanuaryMarch) counts $=13.3$

\footnotetext{
Unless otherwise noted animals were classified in aerial surveys.

${ }^{b}$ Animals classified in ground-based composition counts.

${ }^{\mathrm{A}}$ Animals collected in reduction operations.
} 
sons between populations.

The protracted foaling period (March-July in some horse populations complicates the determination of a parturition peak and population anniversary data. Actually, the annual parturition pattern in many populations probably constitutes an intermediate variant of the "birth-pulse" and birthflow" types (vide: Caughley 1977). Consequently, productivity indices computed from composition counts conducted in virtually any month of the year probably incorporate an unknown source of error as the result of non-discrete generations. Heady and Bartolome (1977) have even suggested a bimodel annual distribution of births, with approximately $10 \%$ of foalings occurring in November. For the purposes of this discussion classification counts conducted in the months January-March and June-August were arbitrarily treated as pre- and post-parturition inventories, respectively.

Another significant source of error is the fact that productivity indices expressed simply as the fraction of young animals in a given population constitute a notably poor statistic for comparison between years or demographic units due to the confounding effects of differing sex ratios. In the case of most of the populations analyzed here the lack of information on the sex composition precluded the computation of more refined measures of productivity (e.g., foals/female).

In view of these problems the mean values given in Table 2 are probably of questionable validity. This notwithstanding, they do indicate that the fraction of foals in the population shrinks considerably during the course of the animals' first year of life. Moreover, most of the figures for the percentage of foals obtained in spring and/or summer counts exceed that $(13 \%)$ obtained in a mid-August classification by Feist and McCullough (1975) for feral horses with a nearly balanced sex ratio (48 males: 52 females) on the Pryor Mountain Wild Horse Range in Montana and Wyoming.

\section{Survival Rates}

A crude approximation of first-year survival may be derived from the shrinkage in the incidence of foals between post-parturition composition surveys and comparable classification counts conducted prior to parturition the following year. Assuming that July and February represent the median months for post-parturition and pre-parturition classifications (as defined above) respectively, then the difference in the mean percentage of foals (Table 2) implies a

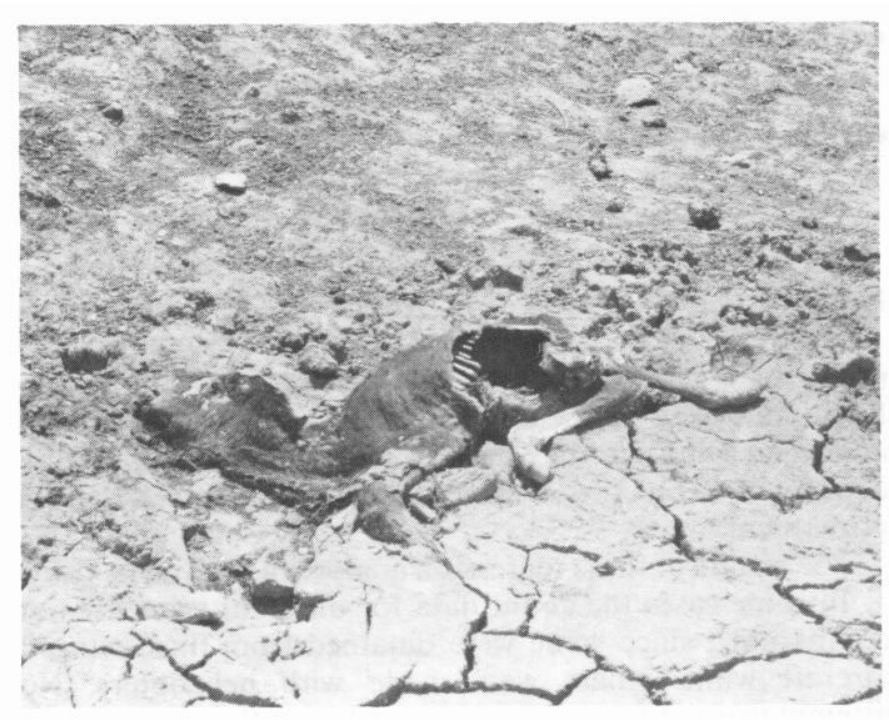

Fig. 2. Feral horses probably sustain substantial losses due to various causes during their first year of life. The photograph shows the carcass of a foal (approximately 1 month old), found dead in June 1977 at the edge of a dried-up waterhole on Douglas Mountain on Dinosaur National Monument, Colorado. Presumably the animal became inextricably mired in the mud earlier in the season, thus meeting its demise.

survival rate of $72 \%$ over the 7 -month interval separating the respective inventories. Such a composite estimate is admittedly speculative because it is based on data from several populations and different years. At best it probably underestimates the total mortality occurring over a 12-month period.

Additional indices of first year survival rates were estimated from the differential incidence of foals and yearlings in time-specific samples from the respective populations as derived either from the composition figures given in Table 2 or from the age distributions of animals captured in reduction operations (Table 3). The "Rawlins" and "Rock Springs" age series in the latter table represent composite samples obtained from populations Wyoming 1-3 and Wyoming 4 and 5, respectively. The implied survival rates estimated by this procedure are given in Table 4 .

The validity of these survival rates is difficult to assess. Intuitively, they appear low. By comparison estimates of first-year survival rates, computed from the data reported by Feist and McCullough (1975) for Pryor Mountain horses

Table 3. Sex and age distribution of animals removed from feral horse populations in reduction operations.

\begin{tabular}{|c|c|c|c|c|c|c|c|c|}
\hline \multirow{3}{*}{$\begin{array}{l}\text { Age class } \\
\text { (years) }\end{array}$} & \multicolumn{8}{|c|}{ Number of animals in respective age classes } \\
\hline & \multicolumn{2}{|c|}{ California-1 } & \multicolumn{2}{|c|}{ Colorado-1 } & \multicolumn{2}{|c|}{ Rawlins composite } & \multicolumn{2}{|c|}{ Rock Springs composite } \\
\hline & Males & Females & Males & Females & Males & Females & Males & Females \\
\hline 0 & 0 & 1 & 26 & 33 & 50 & 73 & 50 & 52 \\
\hline 1 & 19 & 12 & 14 & 27 & 17 & 18 & 15 & 18 \\
\hline 2 & 10 & 9 & 35 & 38 & 37 & 62 & 33 & 29 \\
\hline 3 & 2 & 6 & 9 & 32 & 36 & 70 & 16 & 43 \\
\hline 4 & 1 & 5 & 25 & 24 & 36 & 51 & 20 & 64 \\
\hline 5 & 0 & 6 & 2 & 15 & 3 & 12 & 11 & 18 \\
\hline 6 & 1 & 1 & 17 & 28 & 7 & 24 & 3 & 21 \\
\hline 7 & 3 & 3 & 23 & 15 & 6 & 19 & 4 & 8 \\
\hline 8 & 1 & 2 & 4 & 5 & 10 & 18 & 2 & 7 \\
\hline 9 & 1 & 2 & 10 & 7 & 6 & 9 & 3 & 9 \\
\hline 10 & 0 & 0 & 1 & 4 & 2 & 11 & 0 & 3 \\
\hline $11+$ & 0 & 2 & 11 & 18 & 26 & 38 & 20 & 22 \\
\hline Totals & 38 & 49 & 177 & 246 & 236 & 405 & 177 & 292 \\
\hline
\end{tabular}


Table 4. Estimated first-year survival rates of feral horses.

\begin{tabular}{llc}
\hline & Year & Implicd Survival Rates \\
Population & 1977 & $0.34^{\mathrm{a}}$ \\
\hline Colo-1 & 1977 & $0.70^{\mathrm{b}}$ \\
& Mean & 0.52 \\
Ore-5 & 1975 & $0.52^{\mathrm{b}}$ \\
Utah-1 & 1975 & $0.65^{\mathrm{a}}$ \\
& 1976 & $0.39^{\mathrm{a}}$ \\
& Mean & $0.52^{\mathrm{a}}$ \\
Wyo-1 & 1975 & $0.37^{\mathrm{a}}$ \\
Rawlins & 1977 & $0.28^{\mathrm{b}}$ \\
(compositc) & & \\
Rock Springs & 1977 & $0.30^{\mathrm{b}}$ \\
(composite) & & \\
\hline${ }^{\mathrm{a} C o m p u t e d ~ f r o m ~ t h e ~ r e a l t i v e ~ p e r c e n t a g e s ~ o f ~ f o a l s ~ a n d ~ y e a r l i n g s ~ i n ~ c l a s s i f i c a t i o n ~ s u r-~}$ \\
veys \\
${ }^{\mathrm{b}}$ Computed from the age structure of animals captured in reduction operations
\end{tabular}

range from 75 to $80 \%$. Returning to the populations in question, the survival rates are undoubtedly conservative, because they were estimated from increasing populations. Survival rates estimated from the standing age distribution of a population that has been growing at the same rate (i.e. constant birth and death rates) for some time will be underestimated by a factor equivalent to the rate of increase. Lacking reliable estimates of the growth rates in the respective populations, no attempt was made to adjust the implied survival rates.

Errors in differentiating yearlings from sub-adult and adult animals in classification surveys could also result in underestimation of first year survival rates. Given the protracted parturition period in some feral horse populations and the inherent shortcomings of age determination by criteria of tooth replacement and wear, it is conceivable that a similar bias occurred in the classification of horses handled in round-up operations. From examination of Table 3, it appears that the 2-year old class in Rawlins and Rock Springs samples is disproportionately strong.

In view of these reservations any conclusions regarding juvenile survival in feral horses remain speculative. It does appear, however, that the populations in question sustain substantial first year mortality rates, perhaps approaching $40-50 \%$ in some cases. Considering the harsh and variable nature of the desert and semiarid environments that these animals inhabit, these are probably not unreasonable.

An attempt was made to estimate adult survival rates by the Chapman-Robson method (Robson and Chapman 1961). Explanations and examples of the use of this technique for the estimation of survival rates for large herbivores are given in Eberhardt (1969), Seber (1973), and Kimball and Wolfe (1974). This method allows estimation of a survival rate from the age distribution of a population (or a segment thereof). The technique is predicted on the assumption that the age frequency series constitutes a geometric distribution. In other words, survival is constant in the age classes within the segment of the age series from which the survival rate is computed. The validity of this assumption may be tested statistically by the use of contingency tables and appropriate nonparametric statistics.

For the most part the age distributions given in Table 3 do not constitute geometric series, thereby precluding the relia- ble use of this technique. Given the large sample sizes for the Colorado and Wyoming populations the incongruities in the data are probably attributable to errors in age determination. For example, the Colorado and Wyoming samples obtained in 1977 all reveal an apparently "weak cohort" for the 5-year old class. An additional 119 animals were removed from the Douglas Mountain (Colo-1) population between August 1978 and January 1979, i.e. a year later than the initial collections. The age distribution of those animals was quite comparable to those shown in Table 3 and contained the same apparent discrepancies in the 2- and 5 -year old age classes. This evidence points to a problem in age determination and rules out the possibility of varying cohort strength as the primary source of the observed incongruities in the age structures of the populations in question.

It was possible, however, to estimate survival rates from certain segments of these age distributions by means of the Chapman-Robson model for a truncated geometric distribution. The survival rates thus obtained and their respective confidence intervals $(p \leq 0.05)$ are given in Table 5 . The table also contains survival rates similarly derived from composite samples of males and females from populations in Oregon and Utah. Generically, the Utah sample differs from the others in that it is derived from the age structure of 62 animals that died of an unknown cause at a single location within a period of a few days (July 1976). All the other samples were derived from the age distributions of animals captured alive in reduction operations.

The estimated survival rates in Table 5 are conservatively biased, because they could not be adjusted to account for the growth rates of the respective populations. This notwithstanding, actual survival rates probably exceed the implied values.

This source of error may be partially offset by several counteracting biases arising from the extrapolation of a single survival rate across all "adult" sex and age classes. Among large herbivores, males generally sustain higher mortality rates than females. While this generalization cannot be substantiated statistically from the estimated survival rates, it appears to be compatible with the results shown in

Table 5. Implied adult survival rates of feral horses. .

\begin{tabular}{|c|c|c|c|c|}
\hline Population & $\begin{array}{l}\text { Sex and age } \\
\text { segment }\end{array}$ & $\underset{\text { size }^{b}}{\text { Sample }}$ & $\begin{array}{l}\text { Implied survival } \\
\text { rate and } 95 \% \\
\text { confidence } \\
\text { interval }^{c}\end{array}$ & $\begin{array}{l}x^{2} \text { value for } \\
\text { fit to geomet- } \\
\text { ric } \\
\text { distribution }\end{array}$ \\
\hline Calif-1 & $\begin{array}{l}\text { males }(2-9) \\
\text { females }(2-9)\end{array}$ & $\begin{array}{l}19 \\
40\end{array}$ & $\begin{array}{l}0.67(0.54-0.80) \\
0.79(0.66-0.92)\end{array}$ & $\begin{array}{l}3.36(\mathrm{df}=1) \\
0.43(\mathrm{df}=3)\end{array}$ \\
\hline Colo-1 & females $(2-5)$ & 109 & $0.75(0.69-0.81)$ & $1.41(\mathrm{df}=2)$ \\
\hline Ore -4 & $\begin{array}{l}\text { Composite } \\
(2-9)\end{array}$ & 86 & $0.80(0.71-0.88)$ & $8.30(\mathrm{df}=6)$ \\
\hline Ore-5 & $\begin{array}{l}\text { Composite } \\
(3-9)\end{array}$ & 135 & $0.76(0.68-0.83)$ & $6.05(d f=5)$ \\
\hline $\begin{array}{l}\text { Rock } \\
\text { Springs }\end{array}$ & $\begin{array}{l}\text { males }(2-9) \\
\text { females }(6-9)\end{array}$ & $\begin{array}{l}92 \\
45\end{array}$ & $\begin{array}{l}0.66(0.59-0.74) \\
0.71(0.61-0.81)\end{array}$ & $\begin{array}{l}4.65(\mathrm{df}=3) \\
3.84(\mathrm{df}=2)\end{array}$ \\
\hline Utah-1 & $\begin{array}{l}\text { Composite } \\
(3-9)\end{array}$ & 23 & $0.67(0.51-0.84)$ & $2.27(\mathrm{df}=2)$ \\
\hline
\end{tabular}

${ }^{a}$ Estimated from the age distributions of the respective populations by means of the Chapman-Robson survival estimator Robson and Chapman (1961).

${ }^{b}$ Sample sizes given represent the number of animals in the truncated segments of the age distribution from which the survival rates were computed.

'Survival values given were not adjusted to account for rate of population change. 
Table 6. Results of computer simulation studies of a hypothetical feral horse population.

\begin{tabular}{|c|c|c|c|c|c|}
\hline \multirow[b]{2}{*}{ Case } & \multirow{2}{*}{$\begin{array}{l}\text { Fecundity } \\
\text { (foals/female) }\end{array}$} & \multicolumn{2}{|c|}{ Survival \% } & \multirow{2}{*}{$\begin{array}{c}\lambda \text { (= rate) } \\
\text { of population } \\
\text { change) }\end{array}$} & \multirow{2}{*}{$\begin{array}{c}\text { Years required for } \\
\text { population to } \\
\text { double }\end{array}$} \\
\hline & & Foals & Adults & & \\
\hline I & $1.0 /$ female 4 yrs & 70 & 85 & 1.04 & 18 \\
\hline II & Same as I & 85 & 85 & 1.07 & 10 \\
\hline III & Same as I & 90 & 90 & 1.13 & 6 \\
\hline IV & $1.0 /$ female $\geq 3$ yrs & \multirow{3}{*}{\multicolumn{2}{|c|}{$\begin{array}{l}\text { Same as III } \\
\text { Same as III }\end{array}$}} & 1.17 & 5 \\
\hline V & $1.0 /$ female $\geq 2$ yrs & & & 1.22 & 4 \\
\hline \multirow[t]{3}{*}{ VI } & $0.5 /$ female 2 yrs & & & & \\
\hline & $0.75 /$ female 3 yrs & \multirow[t]{2}{*}{70} & 90 & 1.14 & 6 \\
\hline & $1.0 /$ female $\geq 4$ yrs & & & & \\
\hline
\end{tabular}

Initial population $=200$ animals $($ sex ratio $=50: 50)$

Table 5. Furthermore, survival rates among yearlings are often lower than those in the young and middlc-aged adult age classes. Finally, despite the comparatively small fraction of the population that they comprise, old-age animals are generally subject to higher mortality rates. Thus the estimated survival rates are probably not indicative of the mean rate for all animals older than 1 year. In view of the unknown magnitude of these counteracting biases, the actual adult survival rate remains subject to conjecture. Realistic figures probably lie within the range of 80 to $85 \%$.

\section{Population Simulations}

The dynamics of feral horse populations were investigated further by means of simulation studies. A computer model of a modified Leslie $(1945,1949)$ matrix was employed to determine the projected rates of population increase under varying combinations of fecundity and survival. This program, developed by Innis (1975) allows the manipulation of age- and sex-specific and survival rates as well as several other demographic variables. The pertinent input parameters and results of several simulations are given in Table 6. All runs were executed in deterministic and density-independent mode. In each case the initial population vector comprised a population of 200 animals, apportioned geometrically in 10 age classes, each with an even sex ratio.

The results in Table 6 indicate that a very slowly increasing population $(\lambda=1.04)$ is obtained by applying survival rates of 70 and 85 percent for foals and adults, respectively, and assuming that no mares produce any foals until their fourth year of life. The only conditions that yield an annual increase rate exceeding 20 percent are those of Case $\mathrm{V}$ in which all females breed as yearlings and the annual survival rate for all age classes is $\mathbf{9 0}$ percent.

Comparison of these admittedly artificial results with the "observed" rates of increase of the various populations (Table 1) leaves considerable room for speculation. The primary implications are twofold:

(1) Either the survival rates derived above (especially the rate for foals) are erroneous; or

(2) The seemingly exceptional parameters used in Case V are indeed unrealistic and other factors may account for the observed rates of increase.

Given the crude and fragmentary empirical evidence that presently exists on feral horses, this question cannot be answered conclusively. Intuitively, however, it appears unlikely that survival rates in a free-ranging horse population would exceed considerably $90 \%$. In this respect, the validity of annual rates of increase for feral horse popula-

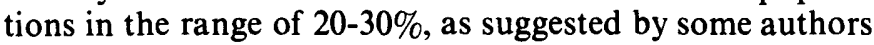

(e.g. Cook 1975, Heady and Bartolome 1977), are highly questionable.

The subject of age-specific reproductive performance, especially that among 2- and 3-year old females remains a virtual unknown in our knowledge of feral horse population biology. Hall (1972) maintained that the majority of mares in the Pryor Mountain herd do not enter estrous until they are three years old. This contention is consistent with the findings of Feist and McCullough (1975) who reported that 7.4 percent of the Pryor Mountain mares classified as 3-year old females bore foals. Likewise, twins are generally considered to be a rarity among equids (Klingel 1969, Tyler 1972). In the Pryor Mountain herd Freist and McCullough (1975) observed only two sets of twins (5.7 percent) among 35 mares which bore foals. In summary, this fragmentary evidence indicates that the reproductive parameters applied in cases IV-VI (Table 6) may indeed be too liberal.

On the other hand, the apparent discrepancies between observed and predicted rates of increase are at least partially attributable to the numerous problems involved in the census procedures (i.e. aerial trend counts) employed. For example, increasing observer experience or differential intensity of aerial counts from one year to the next may be reflected in spurious rates of increase. These and related problems are well documented in the literature with respect to aerial inventories for other ungulates (Gilbert and Grieb 1957, Le Resche and Rausch 1974, Caughley 1974). Frei et al. (1979) contend that a major portion of the purported increases in feral horse populations can be attributed to the noncompensating errors inherent in aerial surveys. This is an admittedly speculative explanation for the problem at hand, but it does underscore the fact that implied rates of increase based on the results of consecutive aerial censuses should hardly be accepted at face value.

\section{Recommendations}

Future classification surveys would yield more useful information if data on the sex composition of the adult segment were collected in addition to that on the relative age structure. This would entail careful classification of animals in ground-based rather than aerial surveys, necessarily with some sacrifice in sample size. Ideally, classifications counts should be conducted shortly following the peak of the parturition period (May/June), while yearling animals are still recognizable as such. Such surveys would be advantageous in several respects. The data thus obtained would permit further correction of productivity indices to exclude largely non-reproducing yearling females. More importantly, the information on the fraction of yearlings present in the popu- 
lation would allow the estimation of first-year mortality rates by the methods described above. Finally, horses exhibit post-partum breeding, with mares coming into estrous after foaling. The associated sexual activity could facilitate sex determination among adult animals.

The estimation of survival rates by the procedures described above would be greatly facilitated by more accurate age determination of animals captured in reduction operations or carcasses found randomly or in systematic searches. Unlike cervids and some other ungulates, horses do not obtain their full complement of permanent teeth until 5 years of age, thus permitting the use of tooth replacement criteria for age determination a mong younger animals. Reliable results are of course predicted on careful examination by experienced personnel. Estimation of age among older animals by tooth wear becomes increasingly difficult and less accurate with increasing age. Indeed these criteria, established for domestic animals (Ensminger 1951), may not apply to free-ranging horses, especially those inhabiting areas of sandy or gritty soils (cf Bone 1964).

These problems might be circumvented by the use of counts of annular structures in cementum of sectioned teeth for age determination. Obviously, the logistics of age determination in horses captured alive are inherently more difficult than is the case for the remains of animals found dead. The animals must be restrained or drugged, whether for the purpose of more than a cursory examination of the dentition or to extract a tooth for sectioning.

Unfortunately, these procedural modifications will not rectify the underlying dilemma of our inability to accurately estimate survival rates from time-specific samples of the age structure of changing populations. A partial solution to this problem may lie in an alternate approach, namely, the estimation of survival rates by following the fate of a single (or multiple) cohorts over time. While by nor means free from error, such an approach is not subject to the restrictive assumption of population stationarity. It would require, however, identification of "sample cohorts" by means of marked animals. This, in turn, would necessitate the establishment of fairly extensive annual trapping and tagging programs for specific populations of interest and the continuation of such programs over a minimum of several years. The actual number of animals that would need to be marked would depend upon several factors, the most significant of which are: (1) size of the population; (2) recapture frequency of previously marked animals; and (3) desired precision of the survival rate estimate. While this approach might reasonably be expected to yield more reliable survival rate estimates, the logistics involved would probably limit its application to a relatively few regional "study" populations rather than as a standardized data source at the local level.

\section{Literature Cited}

Bone, J.F. 1964. The age of the horse. Southwest Veter. 17(4): 269-272. Caughley, G.C. 1974. Bias in aerial survey. J. Wildl. Manage. 38: 921-933. Caughley, G.C. 1977. Analysis of Vertebrate Populations. John Wiley and Sons, London. 234 p.

Cook, C.W. 1975. Wild horses and burros; a new management problem. Rangeman's J. 2: 19-21.

Eberhardt, L.L. 1969. Population analysis. 457-495 In: R.H. Giles, Jr. (ed.). Wildlife Management Techniques, 3rd ed. The Wildlife Society, Washington, D.C. 623 p.

Ensminger, M.E. 1951. Horse Husbandry. Interstate Printers and Publ. Danville, Ill. 336 p.

\section{Appendix}

Coded designations and locations of the feral horse populations analyzed in this study.

\begin{tabular}{ll}
\hline Designation & \multicolumn{1}{c}{ Location and/or administrative unit ${ }^{\mathrm{a}}$} \\
\hline California-1 & Twin Pcaks Management Area, northeastern \\
& California/northwestern Nevada, Susanville \\
& District, California
\end{tabular}

Colorado-1 Douglas Mountain, Dinosaur National Monument, northwestern Colorado

Nevada-1

Massacre Lake Management Area, northwestern Nevada, Susanville District, California

Nevada-2

High Rock Management Area, northwestern Nevada, Susanville District, California

Nevada-3

Tuledad Management Area, northeastern California/northwestern Nevada, Susanville District, California

Nevada-4

White Pine Division, Humboldt National Forest, Ely, Nevada

Oregon-1

Cold Springs Management Area, Vale District, Oregon

Oregon-2

Morger Allotment, Vale District, Oregon

Oregon-3

Sheephead's Basin/Barren Valley, Vale District, Oregon

Oregon-4

Jackie's Butte, Vale District, Oregon

Oregon-5

Three Fingers, Vale District, Oregon

Utah-1

Cedar Mountains, northwestern Utah

Utah-2

Wyoming-1

West Desert Area, western Utah

Wyoming-2

Seven Lakes Planning Unit, Rawlins District, Wyoming

Wyoming-3

Adobe Town, Rawlins District, Wyoming

Wyoming-4

Atlantic Rim, Rawlins District, Wyoming

Little Colorado Area, Rock Springs District,

Wyoming-5 Northeast Area, Rock Springs District, Wyoming

"Unless otherwise specified all management and administrative units involve Bureau of Land Management lands.

Feist, J.D., and D.R. McCullough. 1975. Reproduction in feral horses. J. Reprod. Fert., Suppl. 23: 13-18.

Frei, M.N., J.S. Peterson, and R. Hall. 1979. Aerial census of wild horses in western Utah. J. Range Manage. 32: 8-11.

Gilbert, P.F., and J.R. Grieb. 1957. Comparison of air and ground counts in Colorado. J. Wildl. Manage. 21: 33-37.

Hall, R. 1972. Wild horse: Biology and alternatives for management, Pryor Mountain Wild Horse Range. Bur. Land Manage., Billings District. 67 p.

Heady, H.F., and J. Bartolome. 1977. The Vale rangeland rehabilitation: the desert repaired in southeastern Oregon. USDA, Forest Serv. Resour. Bull. PNW-70, 139 p.

Innis, G.S. 1975. LES User's Manual. Wildl. Sci. Dep. Rep. Ser. No. 1. Utah State University, Logan Utah. 31 p.

Kimball, J.F., and M.L. Wolfe. 1974. Population analysis of a northern Utah elk herd. J. Wildl. Manage. 38: 161-174.

Klingel, H. 1969. Reproduction in the plains zebra, Equus quagga boehmi: Behavior and ecological factors. J. Reprod. Fert., Suppl. 6: 339-345.

Le Resche, R.E., and R.A. Rausch. 1974. Accuracy and precision in aerial moose counting. J. Wild. Manage. 38: 175-182.

Leslie, P.H. 1945. The use of matrices in certain population mathematics. Biometrika 33: 183-212.

Leslie, P.H. 1949. Some further notes on the use of matrices in population mathematics. Biometrika 35: 213-245. 
Robson, D.S., and D.G. Chapman. 1961. Catch curves and mortality rates. Trans. Amer. Fish. Soc. 90: 181-189.

Seber, G.A.F. 1973. The Estimation of Animal Abundance and Related Parameters. Griffin, London. 506 p.
Tyler, S.J. 1972. The behavior and social organization of the New Forest ponies. Anim. Behav. Monogr. 5: 85-196.

U.S. Department of Interior. 1976. Susanville District wild horse and burro statistics. Bureau of Land Manage. (unpublished). 